\title{
GLACIOLOGICAL OBSERVATIONS AROUND MOUNT ATTER, WEST GREENLAND
}

\author{
By Mrahael Holland
}

\begin{abstract}
In an uncompleted paper, the glaciological observations made by the late Michael Holland and his party in the mountainous Sukkertoppen region of West Greenland (lat. $66^{\circ} \mathrm{N}$.) during the summer of 1956 are described. Notes on the features of this region and of the present state of the glaciers were fairly complete; it is felt that these should be put on record as likely to be of use to future workers. It is concluded that in recent years retreat of the main glaciers appears to have been very slight. Pit measurements were made and tabulated and comparisons were made with the earlier findings by Etienne in the same area. No notable difference in the annual accumulation is yet apparent; it is tentatively concluded that there may have been a small increase, but caution is heeded in interpretation as the nearest meteorological stations lie at some distance.
\end{abstract}

RÉsumé. Nous présentons ici le rapport incomplet des observations glaciologiques du groupe de feu Michael Holland effectuées dans le massif de Sukkertoppen-Groenland de l'ouest $\left(66^{\circ} \mathrm{N}\right)$ pendant l'été 1956. Les notes concernant les caractéristiques de cette région et le présent état de ses glaciers sont à peu près complètes; il semble que l'on peut les considérer comme données de base pour les recherches futures. Il en découle que le retrait des principaux glaciers pendant les dernières années est très faible. Des mesures de profils ont été effectuées, dépouillées, et comparées, avec les observations faites par Etienne dans la même région. L'accumulation annuelle ne présente pas de différence sensible quoiqu'il semble qu'elle ait légèrement augmenté. Cette conclusion doit ètre acceptée avec une certaine réserve, comme la station météorologique la plus proche se trouve à une distance notable de la zone de travail.

Zusammenfassung. In einem unvollendeten Artikel werden die gletscherkundlichen Beobachtungen beschrieben, welche der verstorbene Michael Holland und seine Expedition in den Bergen Sukkertoppens im Sommer $195^{6}$ gemacht hat. Die Ausführungen über die Verhältnisse in jenem Gebiet und den gegenwärtigen Stand der Gletscher sind ziemlich vollständig; man hatte den Eindruck, dass solche Ausführungen für später sicher nützlich sind. Es wird der Schluss gezogen, dass der Rückzug der Hauptgletscher in den letzten Jahren offenbar sehr gering war. Messungen in Bohrlöchern wurden durchgeführt. Vergleiche mit den früheren Ergebnissen von Etienne aus derselben Gegend ergaben, dass bisher noch kein merklicher Unterschied in der Akkumulation auftritt. Es wird versuchsweise der Schluss gezogen, dass ein leichtes Anwachsen eingetreten ist, aber bei der Interpretation ist Vorsicht nötig, da die nächsten Stationen ziemlich entfernt liegen.

\section{InTRODUGtory Note by G. MANLey and K. S. SANDFord}

Michael Holland's untimely death, together with Carsten Velsboe, in a phenomenal July storm on the upland ice of north-west Greenland, was reported early in August 1957. He was then in charge of a section of the Danish I.G.Y. party carrying out glaciological investigations organized under the leadership of Dr. Børge Fristrup, who was working with another section elsewhere. In the previous summer of 1956, Michael Holland himself had organized an expedition to the Sukkertoppen region of West Greenland. A general description of the work then undertaken was published in the Geographical Fournal, Vol. I24, Pt. I, $195^{8 .}$

It was his intention to submit a fuller account of the glaciology and geomorphology of the region for publication, and among his papers left at the time of his death are several unfinished drafts and diagrams containing material which would appear to be of value, more particularly for the benefit of future workers in this area. He was much concerned to link his studies with those of earlier Oxford parties and to apply further the ideas developed by E. Etienne who accompanied the $193^{8}$ expedition led by J. G. G. Sugden and P. G. Mott. There are also quantities of original field observations and meteorological data supplied by the Danish Meteorological Institute.

The paper below comprises two sections; the first we have slightly abridged from Holland's own text, keeping to his own wording as far as possible. The second section has been assembled from the notes he had evidently prepared for a lecture. With it we have included the very useful diagrams of which a copy has recently been found among some of his other papers. As his papers were not completed it appears proper to name the other members of his party: Ian Bennett, a graduate in dentistry of Liverpool, now practising in Canada; Ian Morin; Denise Morin (now Mrs. G. Evans, well known among mountaineers), and Gillian Sutton, 
of Somerville College, now studying medicine at St. Mary's Hospital, Paddington. The party spent six strenuous weeks which included a good deal of disturbed weather while camping at high altitudes, and their methods and results should be put on record. Assistance was also given by Miss E. M. Shaw of the Department of Geography, Bedford College, in the compilation of snow data.

\section{Setring*}

In the western coastal regions of Greenland in about latitude $66^{\circ}$ north and $52^{\circ}$ west, an east to west extension of ice breaks the general north to south trend of the margin of the Greenland Ice Sheet. The extension, named the "Sukkertoppen Ice Cap" (Fig. I) after the nearby island settlement, is split into two sections by the irregular and east-west trending Evighedsfjord, and the Oxford University Expeditions of 1935 and 1936 showed that the northern branch is cut off at its eastern end by a deep, steep-sided and ice-filled trench.

The country between the northern branch of the ice cap and Evighedsfjord is alpine in character, and most of the outlet glaciers flowing between the peaks from the northern branch of the Sukkertoppen Ice Cap reach the fjord waters. The mountainous region is one of generally high relief and many of the highest peaks in West Greenland are found there; the highest is Mount Atter (2,190 m.) and is named after Michael Atter who met his death during the Oxford expedition of 1935. Among the peaks are a number of high snow fieldsbasins of accumulation for many other glaciers, some of which fail to reach the sea.

\section{Details of the Area $\dagger$}

Ice accumulates on the slopes of the peaks and on a series of "benches" which are a distinguishing feature of the landscape above $\mathrm{I}, 200 \mathrm{~m}$. To the north the consolidated snow and ice descends from goo to $\mathrm{I}, 200 \mathrm{~m}$. down the sheer northern walls of the massif to the Taterat Glacier and on the south it descends to a snow field, a high basin of accumulation which might be called the "Atter Basin".

There is a marked distinction between the topography above $1,200 \mathrm{~m}$. and that of the country below that level. Above that height are the summit regions of the mountainous massifs and different phases of corrie-type erosion have cut a series of well-marked benches into the peaks. This is the accumulation area; the firn line lay at about $95^{\circ} \mathrm{m}$. in the summer of 1956 . The country below $1,200 \mathrm{~m}$. is characterized by sheer mountain walls, the only relatively flat areas being moraines or the bottoms of valleys between rock steps or ice falls which are a feature of all the valleys. This is the ablation area. The steep walls of the Taterat Range enclose the Taterat Glacier on its western and northern flanks; the culmination of the range is Mount Taterat $\left(\mathrm{I}_{5} 5^{\mathrm{I}} 3 \mathrm{~m}\right.$.) and it is breached in only two places by tributary glaciers, the largest of which is the Igdlo Glacier. Between Survey Glacier and the snout of the Taterat two east-bank tributaries join the Taterat from between deep valleys with remarkably steep sides; they contribute little ice but a large quantity of moraine.

\section{Previous Work}

The area of the Sukkertoppen Ice Cap has been visited by three previous Oxford University expeditions. The first two expeditions in 1935 , led by H. O'B. Hayward, ${ }^{\mathrm{I}}$ and 1936, led by P. G. Mott, ${ }^{2}$ worked on the ice cap's northern and eastern sides and from this base on Sondre Ström Fjord. Journeys were made round and over the ice cap to the mountainous region on the southern side and led to the third expedition in $193^{8}$, under J. C. G. Sugden and P. G. Mott, ${ }^{3}$ which was based on Evighedsfjord. The third expedition concentrated its activities on the lower Taterat Glacier and the Igdlo Glacier and detailed

* See Danish I :5,00o,00o map, Gronland, Geodaetisk Institut, Copenhagen, I954.

$\uparrow$ See Gronland 1:250,000 map 66 V.I Holsteinsborg, Geodaetisk Institut, Copenhagen, 1952. Details of $1: 250,000$ and $1: 25,000$ maps are given in the Polar Record, Vol. 8, No. 52, 1956, p. 39-42. 


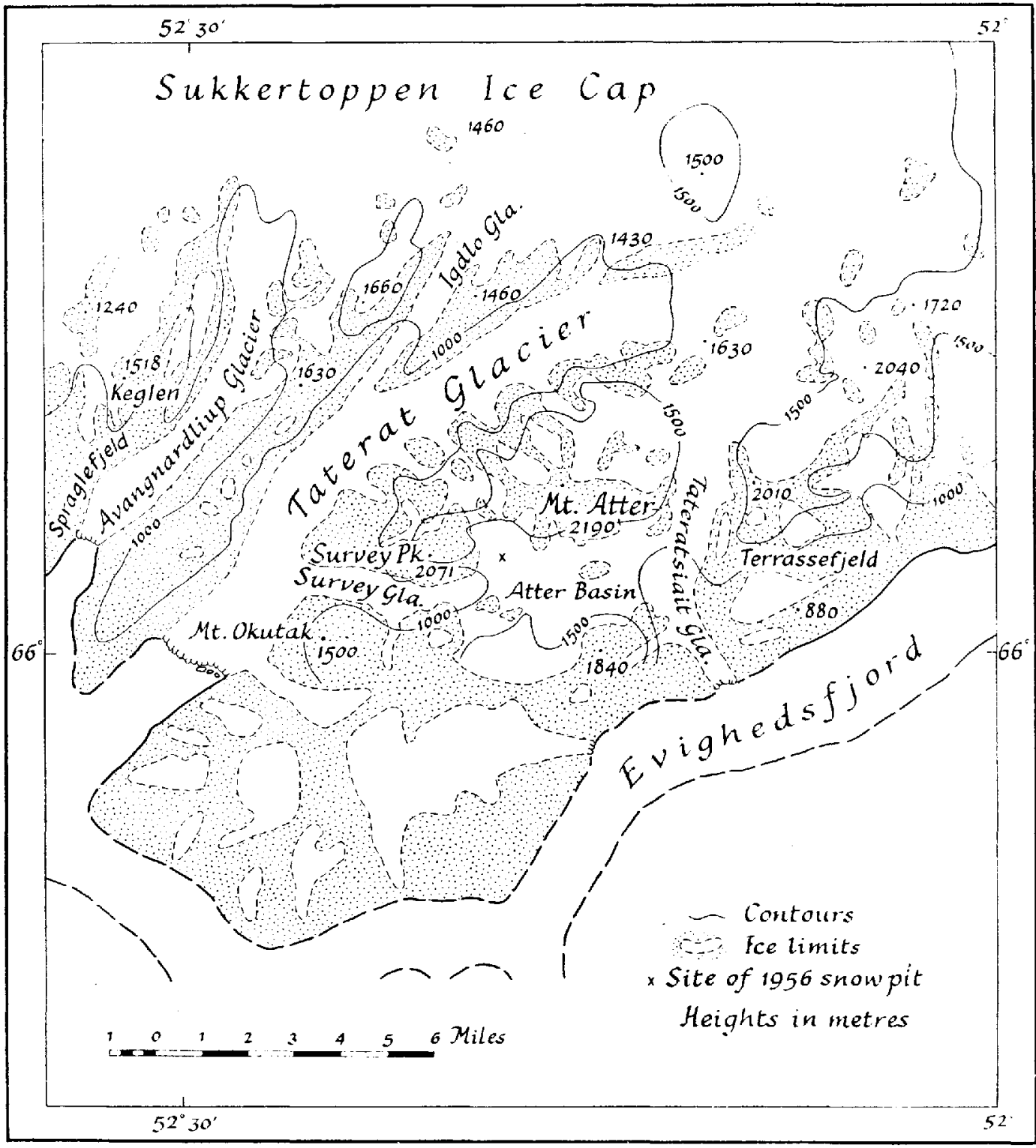

Fig. I. The Sukkertoppen Ice Cap

Courtesy of the "Geographical Fournal"

glaciological studies were carried out and were published in 1940 by Erich Etienne ${ }^{4}$ with a chapter by Mott on. ice movement and a photogrammetric survey.

\section{Conditions in the Accumulation Areas}

The snow falling in the accumulation area collects on the ice cap, on the high glaciers and on the snow fields, and these regions are the largest sources of nevé, but in the mountainous areas quantities of snow gather in the high corries and move out as glaciers to join the ice streams flowing from the main accumulation areas. Avalanches add their quota and 
they are the chief difficulty in attempting to define and limit the accumulation area. If the accumulation area is defined as the region above the upper limit of the firn line then this ignores the amount of snow, firn and ice which falls on to the lower glaciers as avalanches from the mountain sides and from the many hanging glaciers. Firn and ice accumulates on the wide-cut benches and eventually falls to the deeply incised glaciers which are typical of the lower areas of the mountain regions.

There is yet another major difficulty in defining the regions of accumulation and the regions of melting. The upper limit of the firn line on the main ice streams was at about $950 \mathrm{~m}$.; yet avalanches give rise to considerable accumulation of firn and ice here and there on the sides of the glaciers below this line in excess of the summer melting. On the other hand there are many areas above the firn line where melting exceeds accumulation and bare ice surfaces without a cover of firn and snow are common.

There is undoubtedly a question of relief and the character of the erosion of the landscape. Below $\mathrm{I}, 200 \mathrm{~m}$. the dominant erosion is vertical, the incision of the glaciers and the headward retreat of rock steps; above $\mathrm{I}, 200 \mathrm{~m}$. lateral, corrie-type erosion predominates, and instead of deep, gloomy valleys with sheer walls the country is "expansive" and relatively open, so that the effects of solar radiation are noteworthy. Above the firn line the open nature of the country and aspect combine to cause anomalies in the general limit of the firn line. Such anomalies will be rare on north faces, may occur on west- and east-facing slopes, and are common on south faces.

In the north-west corner of the Atter Basin a waterfall flowed down a steep, southwardfacing rock face from an accumulation area at about $\mathrm{I}, 45^{\circ} \mathrm{m}$.; the waterfall never ceased from 7 August to 26 August, yet its source was $300 \mathrm{~m}$. above the firn line. The immediate source was a hole where "dome-fracturing" had caused large blocks of ice to break away. Elsewhere there was plenty of water available for the mechanics of a freeze-thaw process; freezing temperatures occurred every night from 7 August to 26 August, the rock walls were sheer, and corrie-type erosion dominated the scene. The north-facing slopes of the Atter Basin were much more heavily clothed in an ice carapace than the south-facing slopes, and avalanches were much more frequent on the north face.

Water was also common on a high, steep east face in the north-west corner of the Atter Basin and a large, crevassed ablation runnel with quantities of moraine followed the base of the cliff. It is interesting to speculate what happens to the water when it disappears, as it does, beneath the snow surface. On the cliff faces it undoubtedly facilitates the destruction of the rock; all the cliff faces where water flows freely are sheer, rising steeply out of the snow and it is possible that the water assists erosion below the surface of the snow. The water may also carry heat down into the firn and ice and facilitate melting and recrystallization; several thick ice layers were found at depth in a pit sunk into the névé; the water may also eventually freeze and add to the accumulation above the firn line.

Evidence of a decrease in the thickness and area covered by the ice is not pronounced. There has certainly been wastage on the south-facing slopes on the north side of the Atter Basin because the ice stands back from the cliff edges in places as much as $10 \mathrm{~m}$., with moraine lying on the rock between the ice and the cliff edge, which is similar to what occurs at the top of the eastward-facing cliff in the south-west corner of the Basin. An eastwardfacing cliff of "Survey Peak" has that characteristic light-coloured appearance of a cliff-face relatively recently freed of its ice cover. Otherwise there was little to indicate wastage and, as with the anomalies in the firn line, so the position and extent of wastage appear to be controlled by "aspect", the wastage being greatest on south faces, less on east and west faces and nil on north faces. Small areas of stone rills and stone polygons found on the west ridge of Mount Atter to a height of $1,75^{\circ} \mathrm{m}$. show that the ridge has been free of an ice cover for a considerable time. All south faces round the Atter Basin had a flora of sorts, including lichen, and Arctic Poppies were collected on the west ridge of Mount Atter at over $1,800 \mathrm{~m}$. 


\section{Conditions in the Ablation Area}

Ice streams such as the Taterat and the Survey Glacier are typical of the ablation area. There are also corrie ice and corrie glaciers as well as ice lying in large couloirs which latter are especially common on the north faces of the Atter massif. Again there is little to indicate marked wastage.

In all the glaciers reaching sea-level there are three major breaks of slope, in addition to the crevassed zone at the snouts. Streams appeared on the surface only on the comparatively level stretches between the crevassed regions. There are obviously large englacial streams because the volume of the lower surface water could not account for the melt streams which disappear into the crevassed zones. The highest crevassed zone is in the accumulation area, the two lower zones lie in the ablation area.

The lowering of the ice surface is no more than $5 \mathrm{~m}$. at $850 \mathrm{~m}$. a.s.l.* Moraines appear below the firn line though down to $500 \mathrm{~m}$. a.s.l. the accumulation of large avalanche cones at the sides of the glaciers may hide the lateral moraines. Below $700 \mathrm{~m}$. the lateral moraines begin to show above the ice surface, always with ice cores, and where the Survey and Okutak Glaciers join the much larger ice stream of the Taterat Glacier at about $350 \mathrm{~m}$. a.s.1., the system of moraines becomes complicated; but the manner in which the moraines of the tributary glaciers are pushed to the east indicates the pressure exerted by the larger ice stream of the Taterat. At $300 \mathrm{~m}$. a.s.l. the ice-cored lateral and medial moraines are $12 \mathrm{~m}$. high.

At about $35^{\circ} \mathrm{m}$. a.s.l. remnants of the $193^{8}$ camp of Mott were found on the ice. The debris can have moved very little and the reason is probably that there is a large triangle of dead ice between the large stream of the Taterat Glacier and the smaller stream of the tributary Survey Glacier. The wastage for eighteen years is not great. A photograph taken in $193^{8}$ by Mott of the peaks on the east side of the lower Taterat shows ice and snow conditions very little different from those prevailing in 1956 .

On the other hand the highest west bank tributaries moving down from the Sukkertoppen Ice Cap to the Taterat Glacier at about goo $\mathrm{m}$. (that is the two which join, or did join, the Taterat between the Igdlo Glacier, and the head of the main stream) show definite evidence of wastage. The southernmost of the two tributaries now no longer joins the main ice stream and the other shows its wastage in this way.

The Taterat Glacier has three main sources the largest of which is the ice coming in from the north from the Sukkertoppen Ice Cap. From the east ice comes in from a group of heavily ice-covered mountains and from the south a stream of ice comes in from the basin of accumulation between the Atter massif and the Terrassefjeld. All three sources of ice fall steeply over high rock steps to coalesce and make the Taterat Glacier. Although poor weather hindered close examination of the rock exposures in 1956 the indications were that there had been some thinning of the ice passing over the rock steps. This could be critical for the health of the Taterat Glacier because it is possible that a relatively small increase of thinning could turn the rock steps into effective barriers and the large areas of accumulation which supply the glacier might be cut off. This would cause a rapid increase in the wastage of the glacier and the snout would recede quickly because the lower tributaries of the Taterat bring in a small quantity of ice compared with the supply from the three high sources.

Not far from the snout of the Taterat Glacier more camp debris was found, some well above sea level. This may perhaps be from the $193^{8}$ expedition. From a study of the photographs taken by earlier parties 5 and Mott's map ${ }^{2}$ it is clear that the snout has retreated only a few metres in the period $193^{8}$ to $195^{6}$. This is supported by the relative stability of the moraine except that within about $40 \mathrm{~m}$. of the flanks of the south-eastern corner of the glacier adjacent to the snout. The stability indicates that the ice core had melted some

\footnotetext{
* This statement appears to be based on comparison with $1935^{-38}$ photographs. G.M.
} 
distance below the surface of the moraine; even after heavy rain the surface was still in quite good condition. This compares with the snout of the Von Post Glacier in Vestspitsbergen where the unstable ice-cored moraine left recently by the receding ice on the southern side of the fjord is a morasse of solifluxion movement in summer. Furthermore, a lateral streamcut valley in the Taterat moraine trends round to a position parallel to and about $40 \mathrm{~m}$. from the front of the ice; this small valley, where it is at right angles to the general trend of the lateral moraine, indicates a still-stand of the ice front and that the ice front has receded very little.

The front of the south-eastern side of the Taterat Glacier rests full on the edge of a series of rock exposures from 3 to $7 \mathrm{~m}$. high. Any advance or wastage of the glacier can be easily gauged from these exposures and Sugden and Mott's photograph 5 shows the ice in $193^{8}$ to be in roughly the same position with reference to the exposures as it was in 1956 . The rock caused interesting features in the calving at the snout. The north-western side would push forward and then break away along major concave cracks; the south-eastern side, held up by the rock, remained on the edge of the rock exposures and the ice broke away as small pieces and as crumbled powder. No terminal moraine was visible and this may indicate deep water in front of the snout; the glacier is not afloat because a tidal mark is worn into parts of the ice.

\section{Periglacial Conditions}

The stability of the lateral moraine of the Taterat Glacier beyond $45 \mathrm{~m}$. of the edge of the ice and the well-developed flora on the moraine indicate that the ice has made no recent extensive advance from its present position and that a considerable number of years, even centuries, have elapsed since the withdrawal of the ice from the limits of advance shown by the deposition of moraines at the side of the fjord. Even the outwash area in front of the small glacier nearest to the Taterat snout on the south-east side of the fjord is comparatively stable.

A cursory examination showed positive evidence for a major advance of the Taterat Glacier at some earlier stage; no indications of other oscillations in the position of the snout of the glacier were seen but more detailed investigations may prove otherwise. A large lateral moraine extends some $2 \mathrm{~km}$. from the present snout along the south-eastern side of the fjord and there is a small terminal moraine with huge erratics at its seaward extremity. Study of aerial photographs and observations from boats show that moraines are exceptional along the fjord sides; this may be due to the steepness of the fjord walls and the great depth of the water.

The lateral moraine of the Taterat coalesced with moraine from tributary glaciers on the south-eastern side of the fjord giving an abundance of material where the walls have been eroded back by the tributary glaciers. The position of the moraine about $\mathrm{I} \mathrm{km}$. from the snout shows that the surface of the ice was at least $125 \mathrm{~m}$. above present sea-level. Approximately $500 \mathrm{~m}$. from the snout there is a lake dammed between the moraine and the rock wall; this lake bed and another nearby infilled lake would reward augering for possible varve deposits.

At the seaward end of the lateral moraine a dense and complicated flora has developed, especially in a small valley between the crest of the moraine and the rock wall. The indications are that the re-advance of the ice which deposited this moraine took place at least $\mathrm{I}$,ooo years ago, ${ }^{6}$ since when intermittent slow or accelerated overall wastage has taken place. These conditions are, of course, characteristic for most of West Greenland but the ice front now seems to be in a state of equilibrium with the supplies of ice, firn and snow and the amount of seasonal melting.

There is a great cwm on the north-west side of this branch of Evighedsfjord immediately 
south-west of Spreglefjeld. The glacier moving out from this cwm has now wasted back high up the mountain side to leave only a relatively small corrie glacier; similar wastage has happened to a glacier lying in a near-perfect "armchair" corrie at approximately $900 \mathrm{~m}$. on the north-east side of Mount Taterat and to the other glaciers outside the limit of the large ice streams and snow fields. Height for height the nearer the glaciers are to the open sea of Davis Strait the greater has been the wastage of the ice. Several of the cwms, especially the one south-west of Spreglefjeld, have serrated summit lines with deep breaches which may once have been the directions of movement of large and small diffluent glaciers in periods of heavier glacierization.

There are no moraines on the steep south-eastern side of Mount Taterat but a lightcoloured area, in parts the favoured summer habitat of taterats (kittiwakes) and other birds, which appears to have no lithological difference from adjacent rock, extends over $100 \mathrm{~m}$. above sea-level, the upper limit trending down towards sea-level further from the snout. The light colour may be due to a relatively less severe weathering and poorer development of its lichen cover, even though the area does have lichen and plants growing on it. The area is not, as has been suggested, related to the rocks inhabited by the birds. The area corresponds to and may show the advance of the ice proved by the moraine on the southeastern side of the fjord.

\section{Conclusions}

Retreat has occurred, but in recent years appears to have been very slight. Comments on the variation of temperature and precipitation in relation to the accumulation in recent years are made below. These are largely based on measurements made in a pit at $1,200 \mathrm{~m}$, i.e. within the accumulation zone.

\section{GLACIOLOGICAL WORK IN 1956}

\section{Pit Stratification and Measurements, Sukkertoppen Ige Gap}

A pit was excavated on the main glacier $7 \mathrm{~m}$. deep and at an altitude of $1,200 \mathrm{~m}$., about 250 to $300 \mathrm{~m}$. above the prevailing firn line. The pit was in the central area of a basin more or less surrounded by peaks rising to $2,300 \mathrm{~m}$. The location is about $50 \mathrm{~km}$. from the outer coast (lat. $66^{\circ} \mathrm{oI}^{\prime}$ N., long. $5^{\circ}{ }^{\circ} 5^{\prime}$ W.). Successive layers within the firn were thus exposed and density samples taken. From the seasonal and annual accumulations and the average densities of the layers the water equivalents for the seasonal and annual accumulations were obtained.*

Firn densities, from the surface layer, were found to be greater in summer than in winter. There is also a tendency for greater precipitation in summer; therefore the water equivalent is also greater in the summer. This assists the identification of the annual bands. Ice layers, as elsewhere, were found to be discontinuous.

To determine how the rate of accumulation is related to the climatic elements over a period presents some difficulty as the nearest reasonably reliable meteorological records are kept at some distance. Kornok, the nearest, is about $\mathrm{I} 6 \mathrm{o} \mathrm{km}$. distant. Moreover, it lies some distance within the fjords and south of the Sukkertoppen Ice Cap, so that the precipitation measurements in particular may not be wholly representative (Figs. 2 and 3 ).

Godthaab itself on the outer coast lies further away; after consideration, the presumed precipitation (based on the accumulation) for the past I I years has therefore been compared with that at Kornok, using the data supplied by the Danish Meteorological Institute. There

* It is interesting to note that Holland's figure of total accumulation during the years $1948-56$ is given as $274 \cdot 25 \mathrm{~cm}$. Etienne's figures for the same period of time, $1930-3^{8}$, give a total of $271 \cdot 05 \mathrm{~cm}$. These figures are shown in a detailed Table not printed here. G.M. 


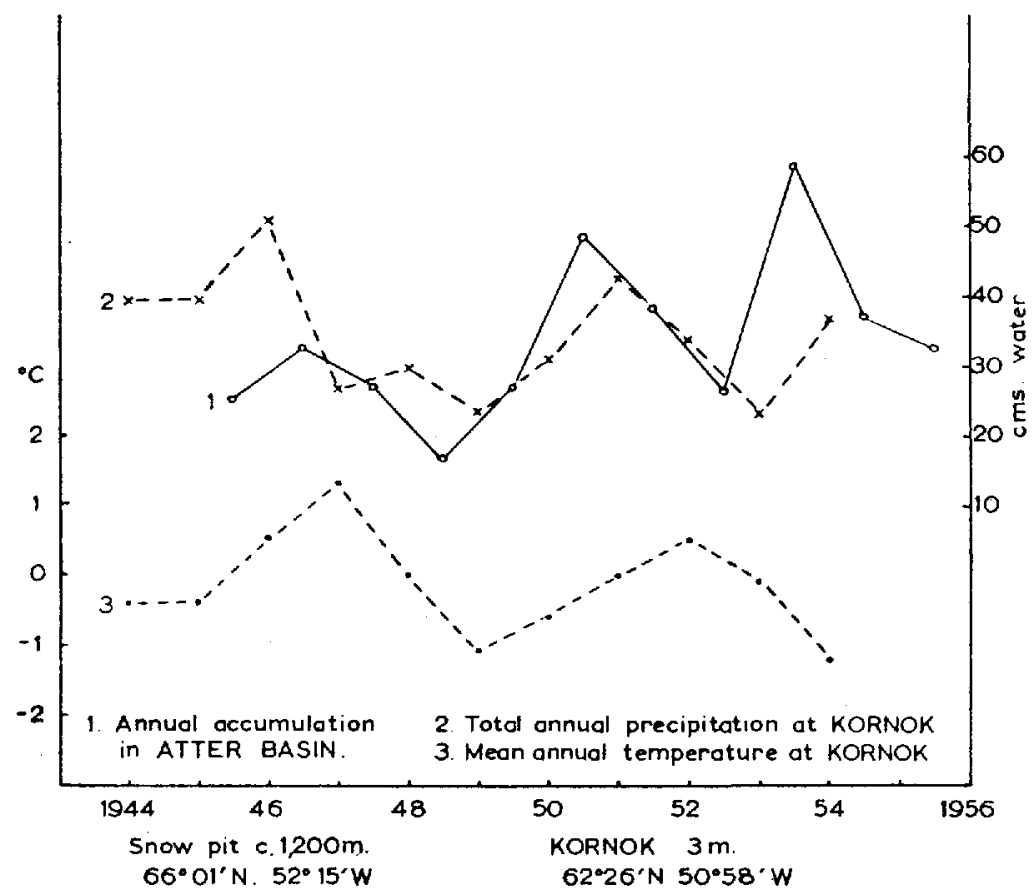

Fig. 2. Accumulation in Atter Basin, and precipitation and mean annual temperature at Kornok

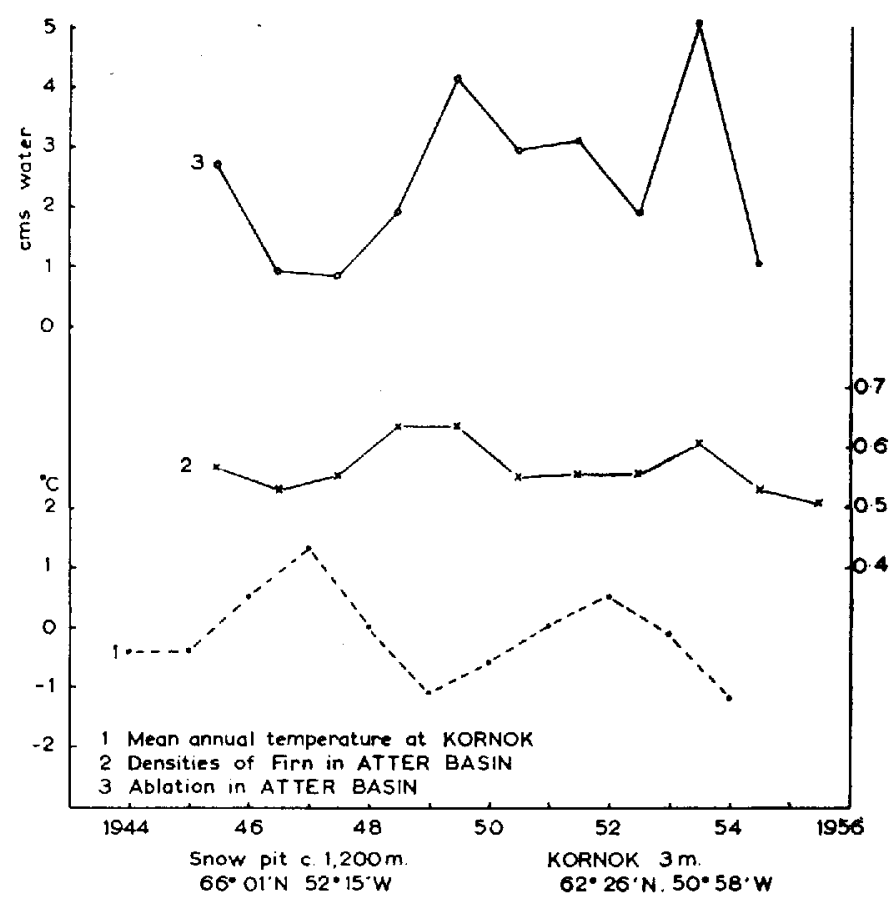

Fig. 3. Ablation and densities of firn in Atter Basin compared with the mean annual temperature at Kornok 
is a reasonable correlation, which agrees with Etienne's findings. As Figure I shows, the agreement with the mean annual temperature at Kornok is less evident.

To determine how the rate of ablation compares with other climatic elements is desirable, but the amount of the ablation is very difficult to ascertain in a short summer expedition. Etienne attempted a method which he describes; he decided that the ablation tended to increase with the mean annual temperature and that as ablation increased so did the density. He took the figure 0.52 to be the density of true firn which has not undergone melting nor accretion of melt water from higher in the profile. He then plotted his ablation against mean annual temperature and against density, and deduced the above relationship.

My own figures from the $195^{6}$ pit show that density increases as ablation increases, but the relationship with mean annual temperature does not agree with Etienne's deductions.

Tentatively we may conclude that, from the more recent period of years, there has been a slight overall increase in accumulation. Mean annual temperatures at Kornok show a tendency to fall. Ablation as shown by the $195^{6}$ profile shows a slight but significant decrease. This combination of factors, if continued, would probably lead to an increase in the volume of the ice and an advance of the ice front.

Any attempt at far-reaching conclusions from one profile must however be treated with great caution. None the less, as the main accumulation area of Survey Glacier within the Atter Basin is about $2.8 \mathrm{~km}$. $^{2}$ in extent, a small increase in volume would ultimately have a considerable effect at the snout, bearing in mind the quite narrow outlet of this glacier.*

It is to be noted that, while the prevailing firn line on the main ice streams lies at about $95^{\circ} \mathrm{m}$., there is a marked difference in the prevailing relief at about I,200 $\mathrm{m}$. Above the firn line there are many areas where melting exceeds accumulation, and bare ice surfaces are common. This is partly because above $1,200 \mathrm{~m}$. the landscape is "expansive" and better exposed to radiation and perhaps also to wind. Therefore, the varying nature of the country leads to marked local variations in the firn line, and these anomalies may well lead to difficulty in giving a true picture of the amount and rate of annual accumulation in a single pit profile.

Evidence for a decrease in the ice cover is not pronounced. Moraines stand at the edge of cliffs, some cliffs have the very fresh appearance of rock recently relieved of its ice cover, photographs show a very slight decrease since 1938 in the volume of the glacier. The surface has been lowered by perhaps $5 \mathrm{~m}$. + There were indications of wastage on the upper Taterat glacier. One tributary shown on the aerial photographs and on the Danish maps to join the Taterat now no longer does so. But, in general, indications of wastage are, not large.

MS. received 26 May 1960

\section{REFERENGES}

1. Hayward, H. O'B. The Oxford University Greenland Expedition, 1935. Geographical Journal, Vol. 88, No. 2, 1936, p. $148-64$.

2. Mott, P. G. The Oxford University Greenland Expedition, West Greenland, 1936. Geographical Journal, Vol. 9o, No. 4, 1937, p. 315-34.

3. Sugden, J. C., and Mott, P. G. Oxford University Greenland Expedition, 1938. Geographical Fournal, Vol. 95, No. I, 1940, p. 43-51.

4. Etienne, E. Expeditionsbericht der Grönland-Expedition der Universität Oxford 1938. Veröfentlichungen des Geophysikalischen Instiluts der Universität Leipzig, Zweite Serie, Bd. I3, 1940, 227 p.

5. Sugden, J. C., and Mott, P. G. op. cit., p. 44.

6. White, S. E. Glaciological studies of two outlet glaciers, north-west Greenland, 1953. Meddelelser om Gronland, Bd. 137, Nr. 8 , 1956, p. 5-31.

* For these reasons this glacier might be well worthy of further watching by future parties, as a potential climatic indicator. G.M.

$\dagger$ This estimate appears to be based on the altitude at which moraines begin to show above the surface of the ice, comparing two photographs. G.M. 